\title{
Working
}

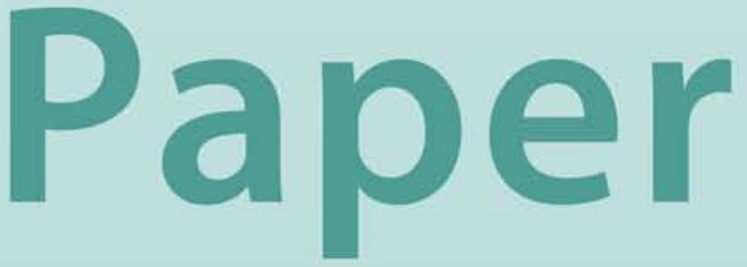




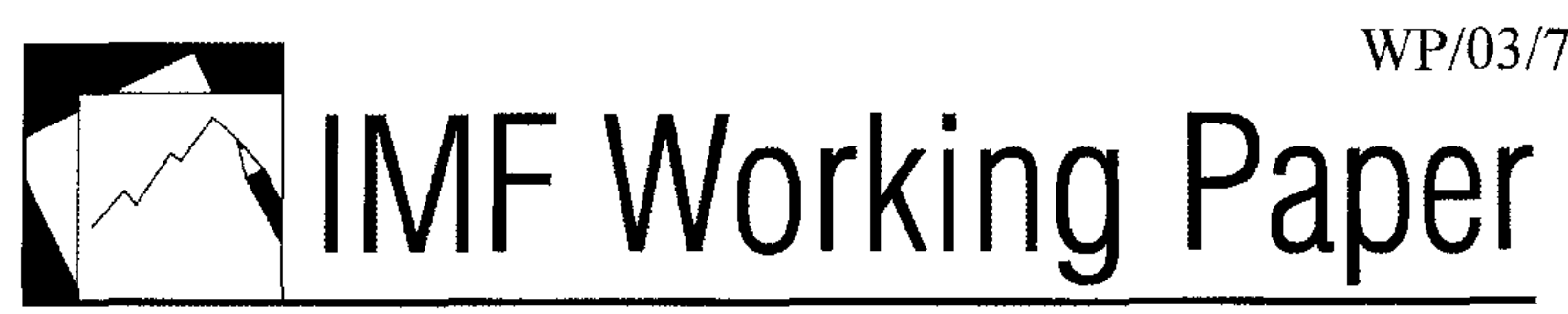

Currency Demand, the Underground Economy, and Tax Evasion: The Case of Guyana

Ebrima Faal

INTERNATIONAL MONETARY FUND 


\title{
IMF Working Paper
}

Western Hemisphere Department

\section{Currency Demand, the Underground Economy, and, Tax Evasion-The Case of Guyana}

\author{
Prepared by Ebrima Faal ${ }^{1}$ \\ Authorized for distribution by Jorge P. Guzmán
}

January 2003

\begin{abstract}
The views expressed in this Working Paper are those of the author(s) and do not necessarily represent those of the IMF or IMF policy. Working Papers describe research in progress by the author(s) and are published to elicit comments and to further debate.
\end{abstract}

The persistence in Guyana of a substantial underground economy is an important consequence of economic and social policy over 1964-2000. The paper attempts to estimate the magnitude of, and changes to the underground economy in Guyana, as well as its adverse effect on tax collection, during this period.

JEL Classification Numbers: C5, E6, H2, O54

Keywords: Underground economy, Guyana, tax evasion

Author's E-Mail Address: efaal@imf.org

\footnotetext{
${ }^{1}$ I would like to thank Katherine Marshall, IMF Office Guyana, for excellent research support and various colleagues for very helpful comments and suggestions. Any errors and omissions are my own.
} 


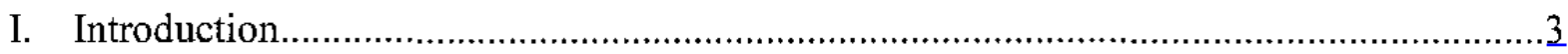

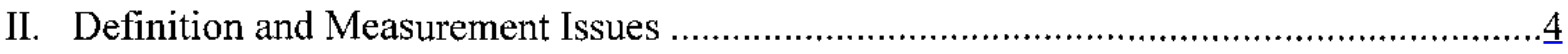

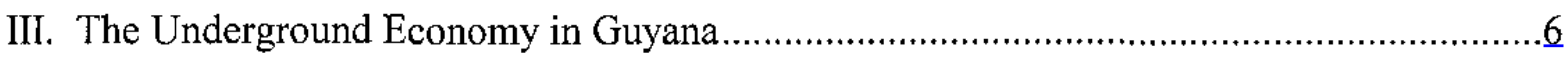

IV. Estimating the Size of the Underground Economy for Guyana.......................................

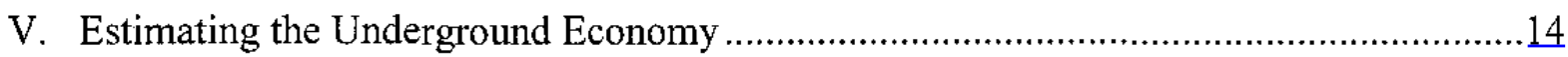

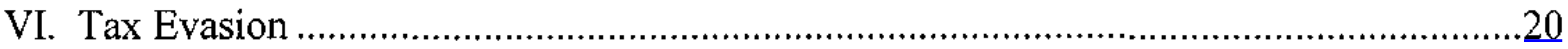

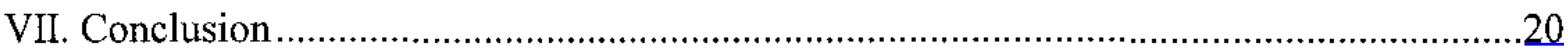

Tables

1. Taxonomy of Underground Economy Activity ...........................................................

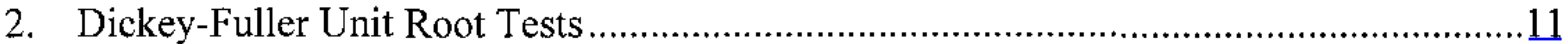

3. Estimation Results Unrestricted Model ..................................................................13

4. Estimation Results Restricted Model...................................................................14

5. Estimates of the Underground Economy and Tax Evasion 1970-2000 ……..................16

\section{Figures}

1. The Underground Economy, 1970-2000 (3-year moving average) ………...................17

2. Real Growth Rates, 1970-2000 (3-year moving average)..............................................18

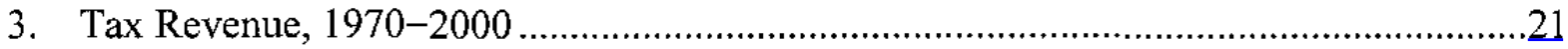

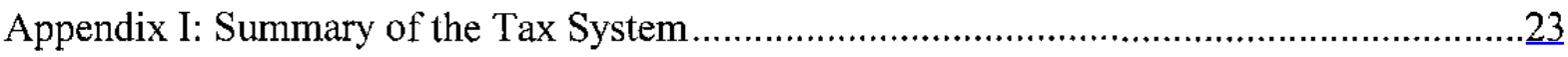

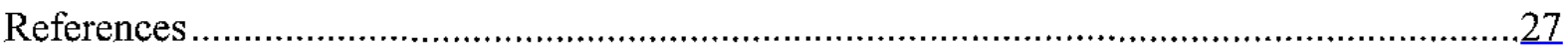




\section{INTRODUCTION}

One of the major problems in formulating economic policy in Guyana is the absence of reliable, accurate, timely, and consistent official economic and social statistics. In particular, although national accounts statistics are usually compiled in line with the conventional guidelines of the System of National Accounts (1993), official national income statistics suffer from both incomplete coverage and inaccuracies in the valuation of economic activities. Deficiencies in estimation techniques and difficulties associated with data collection lead to misreporting and underreporting of national accounts statistics. Also, economic agents deliberately conceal information from the authorities either because they are involved in illegal activity, or if the activity is legal, there is a conscious effort to avoid paying taxes. These activities are usually conducted in the underground economy. Obtaining accurate statistics about economic activities and the allocation of economic resources in the underground economy is important for the formulation and implementation of effective economic and social policies.

The presence of a large underground economy undermines government revenue collection, while increasing the cost of providing public services. For these reasons, it is crucial to know who is engaged in the underground economy, with what frequency, and more importantly, the magnitude of their activities in order to assess the implications for national account statistics and fiscal revenues.

Approaches to measuring the size of the underground economy have been an important concern of policymakers since the late 1970 s for many reasons. ${ }^{2}$ The presence of a large and growing underground economy understates the size of the economy, signals the existence of market distortions and excessive regulations, and raises governance issues. It therefore sends inaccurate signals about the state of the economy and leads to suboptimal policy recommendations and outcomes (see Frey and Pommerrehne, 1984). In studies, initially based on market economies, it was the rising budget deficits and other public choice issues that sparked research interest in this area. However, in economies like Guyana with substantial state intervention in the 1970 s and 1980 s, the underground economy was, in part, associated with pervasive regulations of the productive sectors and markets and the ensuing shortages.

In the past, the underground economy in Guyana was considered to be "as large as the official economy." Thomas (1989) refers to the widely held view in Guyana that the underground economy amounted to between 80 and 100 percent of the official economy during the $1980 \mathrm{~s}$. Empirical studies have indeed found the size of the underground economy to be large.

\footnotetext{
${ }^{2}$ Schneider and Enste (2000b) provide an excellent survey of the literature on the underground economy.
} 
Thomas used trend line analysis of income velocities with respect to currency to obtain estimates of the underground economy that range from 26 percent to 99 percent of the official economy during 1982-86. In another study covering the period 1979-89, Bennett (1995) estimated a currency ratio model for Guyana and found that the size of the informal sector of Guyana was about one-third of the official economy.

This study differs from these earlier studies for Guyana in three important respects. First, to improve on the validity and robustness of previous estimates, we use an alternative econometric method based on a variant of Tanzi's currency demand approach and an error correction model (ECM) to derive estimates of the underground economy. A useful feature of this approach is that it allows for other explanatory variables in modeling the behavior of currency balances. Second, in our model, in addition to the standard demand for money arguments, we incorporate a measure of "excess sensitivity" to taxes (Bajada, 1999), and financial innovations that theory suggests can be important in explaining currency holdings. Third, some official statistics have been revised since the Thomas and Bennett studies. To generate more robust results, this study incorporates these revisions in the data and extends the time series data to cover 1964-2000.

The rest of the paper is organized as follows: Section II discusses the definition and scope of the underground economy and reviews the main empirical issues in the economic literature. Section III discusses some of the salient features of the underground economy in Guyana. Section IV presents time series estimates of demand for currency holdings, while Section V presents estimates of the size of the underground economy. The implication for tax policy and estimates of the scope of tax evasion in Guyana is presented in Section VI. Section VII concludes the paper by bringing together the main aspects of the analysis and discussing the role of policy in reducing the size of the underground economy.

\section{DEFinition AND MeASUREMENT ISSUES}

By its very nature, any attempt to estimate the size of the underground economy must first deal with the problem of defining it. As the nomenclature suggests, it is by definition a concealed activity and therefore, direct observation by statisticians is impossible. As a result, the econometric estimation of the underground economy, for the most part, is carried out with techniques of indirect observation through the use of proxies. ${ }^{3}$

The definition of the underground economy often differs with the objective and approach of the study, but in general, it encompasses a myriad of activities that are deemed to be both

${ }^{3}$ For a discussion of and application of the various methodologies see Tanzi (1992), Bhattacharyya (1990), and Schneider and Enste (2000a). 
legal and illegal. Feige (1979) defines the underground economy to encompass all unreported activity that goes unmeasured "by society's current techniques for monitoring economic activity." Smith (1994) defines it as "market based production of goods and services, whether legal or illegal, that escapes the official estimates of GDP." These definitions adopt a broad view of the underground economy to include both legal (unreported income that would normally be recorded in GDP) and illegal activities such as prostitution, money laundering, and drug trafficking.

Table 1. Taxonomy of Underground Economy Activity

\section{Monetary Transactions}

1. Illegal activities Trade in stolen goods

- Drug dealing and manufacturing

- Gambling and racketeering

- Prostitution

- Money laundering

- Smuggling

- Fraud

\section{Legal activities}

Tax evasion

- Unreported income (profits, rental income, tips, etc.)

- Wages, salaries, and assets from unreported work related to legal goods and services

- Under invoicing

Tax avoidance

- Employee discounts

- Fringe benefits

\section{Nonmonetary Transactions}

- Barter of drugs

- Theft for own use

- Production of drugs for own use

Tax evasion

- Barter of legal goods and services

Tax avoidance

- All do-it-yourself and other unpaid help

Source: Schneider and Enste (2000b, p. 79), with some modifications.

A somewhat different emphasis is provided by Tanzi (1980, 1982), Tucker (1982), and Schneider (1986) as they restricted themselves to measuring the extent by which official statistics are distorted, namely the extent to which fiscal income is evaded or goes underreported. This definition identifies, as potential distortions to the measurement of aggregate economic activity, all unreported income which has contributed to value added 
according to the System of National Accounts (1993), but which is not included in the official statistics. These include unreported profits, interest income, rental income and receipt of tips, welfare benefits, moonlighting, domestic employment, under invoicing, and exchange of professional services (barter). Table 1 provides a useful reference for developing a consensus definition of legal and illegal activities in the underground economy.

The definition used in this paper follows that of Tanzi $(1980,1983)$ and of Schneider (1986) and defines the underground economy to comprise income generated from activities that are concealed from the tax authorities in an attempt to evade taxes. This includes parallel and black market activities and the informal sector. While it is common to use the terms parallel and black markets interchangeably, it is important to view them as describing differing phenomena since they do have different implications for policy. The parallel market involves the illegal production and distribution of goods and services that are legal and have an alternative legal market. Parallel market activities often develop to maximize the huge rents associated with excessive government interventions and restrictions in goods or factor markets. Black market activities involve the production and distribution of market and nonmarket goods that are illegal and strictly forbidden by government law. The informal sector is used to describe very small-scale units that are engaged in the production and distribution of goods and services by both employed workers and the self-employed. They are informal, since in the main, they are unregistered, unrecorded, and in the rural areas have little or no access to formal education, credit facilities, and organized markets.

The considerable attention given to the definition and measurement of the underground economy reflects a concern regarding the sub optimal allocation of resources. If the underground economy is large and growing rapidly, then it implies a shrinking of the tax base, while at the same time, placing large demands on public expenditures as public services provided are consumed by entities in both the official and underground sectors.

\section{THE UNDERGROUND ECONOMY IN GUYANA}

Gathering information about the underground economy is difficult since no one engaged in this sector wants to be identified. Nevertheless, the evidence tends to suggest that participation in the underground economy in Guyana became widespread in the 1970 s and 1980s for several reasons. First, it compensated for the weak functioning of the official Guyanese economy and offered consumers access to goods and services that were not available in the official economy because of inadequate supply. Second, it provided opportunities for entrepreneurs, who could not otherwise participate in the official economy, to profit from the critical shortages of goods and services in the latter economy by adopting strategies that were not approved by the government.

Third, during 1975-87, import substitution and nationalization policies formed a major part of Guyana's development strategy. Foreign exchange was strictly rationed at the fixed 
exchange rate. High tariffs and a complex system of import licensing requirements were put in place to encourage import substitution and a high degree of self-sufficiency. A ban was placed on the importation of a range of consumer goods in order to foster the development of import substitution industries. The pattern of protection had many effects. Direct restrictions on imports and distortions introduced by quantitative restrictions and tariffs resulted in a highly protected domestic market with a high cost structure, while demand for goods and services remained unfulfilled. Moreover, the emphasis on state ownership of the factors of production and controls on foreign exchange and investment limited the opportunity for private sector initiatives. The excessive interference by the state in the economy, poorly designed regulations, and an overvalued currency in the official foreign exchange market led to favorable conditions for the rapid growth of rent seeking activities and the institutionalization of the underground economy. ${ }^{4}$

With the liberalization of the economy beginning in 1988, profits in the parallel economy were eroded as controls on trade, foreign exchange, and prices were removed. The incentive to engage in underground activity was reduced as the supply of commodities increased in official markets. With these favorable conditions, and as the economy transitioned toward a market-based economy, the size of the underground economy diminished somewhat and the formal economy grew.

Nonetheless, the underground economy remained large mainly reflecting the still burdensome regulatory environment combined with inefficiency of public institutions; a distortionary system of taxation; weak tax collection and enforcement; and a large informal sector. As a result, a significant share of economic activity remained in the underground economy during the 1990s. We can classify the entities operating in the underground economy into two broad categories. The first group includes entities that carry out value-added activities producing goods and services, without paying taxes to the government. This group ranges from the small entrepreneur - such as vendors, craftsmen, and tradesmen - and professionals - such as lawyers and doctors - to large family-owned companies. Their participation in the underground economy usually reflects a desire to evade high corporate and personal tax payments. 5

The second group includes entities/persons who are involved in clandestine activities. The range and scope of this group's activities is difficult to judge, but would entail the use of cash

\footnotetext{
${ }^{4}$ See Egoumé-Bossogo, Faal, Weisman, and Nallari (2002) for a detailed discussion of economic policy in Guyana since 1970.

${ }^{5}$ In addition to a 2 percent minimum turnover tax, companies pay $35-45$ percent of profits in taxes and for certain consumer items more than 100 percent of the value is levied as import taxes and duties (see Appendix I for a summary of the tax system).
} 
as a preferred mode of conducting business. Like the first group, participants in the second group engage in the underground economy in search of greater disposable incomes and are driven there mainly for institutional, legal, and economic reasons.

\section{Estimating The Size OF THE UndERGROUND ECONOMY FOR GUYANA}

Cagan (1958) provided the first attempt to investigate the size of the underground economy using monetary variables as a proxy. Cagan's approach to modeling the underground economy assumed that the share of currency in the money supply in a base year was representative of the behavior of economic agents. The residuals around this ratio, together with a velocity assumption, were then used to gauge the size of the underground economy. ${ }^{6}$ Similar approaches based on the assumption that proceeds of the underground economy were laundered through currency and currency substitutes were adopted by Guttman (1977) and Feige (1979); these approaches did not use statistical techniques procedures but rather concentrated only on the ratio of currency to demand deposits.

Tanzi $(1980,1983)$ modified Cagan's approach by estimating a currency demand function for the United States for 1929-80. In his approach, the influence of the underground economy on currency demand, proxied by tax rates to indicate the incentive to avoid taxes and participate in a cash-based underground economy, was estimated directly in the regressing equation linking currency demand and tax rates. With the key assumption that underground economy transactions are conducted in cash, an increase in the size of the underground economy increases the demand for currency and vice versa. ${ }^{7}$

The model estimated here uses a demand for currency specification to measure the size of the underground economy by looking at the excess sensitivity of real currency holdings to average tax rates (Bajada, 1999). That is, the model measures whether changes in tax rates changes currency holdings in addition to the expected effects on disposable income. As currency is part of money demand, our model has the standard demand for money arguments (income and opportunity costs of holding currency) and also incorporates the average tax rates and a variable to capture financial innovations and other structural changes in the financial sector. ${ }^{8}$ Tax rates can affect currency holding by creating incentives to avoid tax

${ }^{6}$ The residuals around this ratio were assumed to reflect money laundering, and were used together with the velocity assumption to measure the underground economy.

${ }^{7}$ The Tanzi approach has been criticized by Thomas (1999) and addressed in Bhattacharyya (1999). In general, the Tanzi approach is superior to Guttman's currency deposit ratio in that it does not assume constancy in the currency deposit ratio or a base year.

${ }^{8}$ The average tax rate is used to proxy marginal tax rates, which is not readily available. 
payments by engaging in more cash transactions. Since we are interested in the excess sensitivity of taxes, we use disposable income, rather than gross income as an explanatory variable, and expect this variable to be positively correlated with currency demand. Financial innovations can affect desired currency holdings by influencing the transaction cost of holding money. In its most general form, demand for currency can be written as follows:

$$
C=f\left(Y^{d}, R, \pi, F\right)
$$

Since disposable income is defined as income net of direct taxes, equation (1) can be written as: ${ }^{9}$

$$
C=f(Y-T, R, \pi, F)
$$

According to the conventional demand for money specification, (C) is the sum of currency demanded for the economy as a whole (both official and underground). A rise in disposable incomes $\left(\mathrm{Y}^{\mathrm{d}}\right)$ will increase currency demand, while a rise in the opportunity costs of holding money-interest rate $(\mathrm{R})$ and the inflation rate $(\pi)$-or financial innovations will reduce demand for currency. Given the key assumption in the Tanzi approach that the underground economy is more cash intensive than the official economy, an increase in taxes is expected to increase demand for currency. Cagan (1958) and Tanzi (1982) have found evidence of such a relationship. ${ }^{10}$

The period 1994-2000 saw significant financial innovations and technological changes in the Guyanese financial system. The expansion of bank branches, the introduction of checkable savings deposits, the computerization of banking services, and the proliferation of automatic teller machines (ATMs) were key advances. In this era, the cost of obtaining currency depends on the number of ATMs and the number of branches of financial institutions. In a real sense, ATMs and bank branches have become close substitutes so that for the purposes of this paper we regard ATMs as branch networks of banks. ${ }^{11}$ As a result, the financial innovation variable, $F$, is the sum of the number of bank branches and the number of ATMs. Improvements in banking services would, according to the transactions demand model (Baumol, 1952), lower the demand for currency.

\footnotetext{
${ }^{9}$ Transfers in the form of welfare benefits are negligible and assumed to be zero.

${ }^{10}$ In the absence of proper records and documentation, including bank records, the revenue authority cannot detect a person's tax liability. It is, therefore, in the interest of those who wish to evade taxes to explicitly request payments in cash.
}

${ }^{11}$ See Hill and Kabir (2000) for a similar treatment. 
Thus our formulation for the estimation of currency demand is:

$$
\mathrm{C}=\mathrm{f}(\mathrm{Y}-\mathrm{T}, \mathrm{R}, \pi, \mathrm{F}, \mathrm{T})
$$

\section{Definition of the data}

The data consists of annual observations from 1964 to 2000 and are taken from two sources: the International Financial Statistics (published by IMF) and the Bank of Guyana Statistical Bulletins. Real currency holding $(C)$ is measured by nominal currency deflated by the implicit GDP deflator; real income in 1988 prices is measured by GDP (income based at current prices less direct taxes) deflated by the implicit GDP deflator; the average tax rate (T) is calculated as direct taxes on income and imports (current prices) expressed as a percent of GDP; the opportunity costs variable (R) and inflation $(\pi)$ are measured by the 91 -day treasury bill rate and the percentage change in the implicit GDP deflator respectively. (F) represent financial innovation and structural change, which is proxied by the sum of ATM machines and bank branches.

\section{Estimation of currency demand}

In traditional estimates of currency demand, the adjustment of actual currency demand toward the long run desired currency demand was typically modeled by a partial adjustment mechanism. However, in recent years, various error correction models have been used to model dynamic adjustment to long run equilibrium. This paper follows this approach. It is well known that if the time series is not stationary, the distributions of the conventional test statistics are not the same as those derived under the stationarity assumption. In that event, no asymptotically correct critical values for the conventional significance tests exist. As a result, time series data must be investigated for stationarity.

To do so, we first identified which of the variables in our model follow a random walk by taking the natural logarithm of each variable and testing for the presence of a unit root. The results are reported in Table 2. All variables exhibited evidence of a unit root in their levels. To test for a second unit root we redid the tests on the first differences of the variables and established that none of the variables contain more than one unit root. ${ }^{12}$ In other words, all the variables are nonstationary in levels but are clearly stationary when they are first differenced; i.e., integrated of order 1 or I (1). This suggests that the variables are indeed cointegrated since the calculated t-statistics from the Augmented Dickey-Fuller equations are larger in absolute terms than the critical values at 5 percent level of significance.

${ }^{12}$ A useful review and applications of unit root tests can be found in Perron (1989) and Phillips and Perron (1988). 
The preferred specification follows a general to specific modeling strategy and estimates a general dynamic error-correction model (ECM). The general specification we consider takes the form of an autoregressive distributed lag model of the type below: ${ }^{13}$

$\Delta \ln \left(\mathrm{C}_{\mathrm{t}}\right)=\alpha_{1} \Delta \ln \left(\mathrm{Y}_{\mathrm{t}}^{\mathrm{d}}\right)+\alpha_{2} \Delta \ln \left(\mathrm{T}_{\mathrm{t}}\right)+\alpha_{3} \Delta \ln \left(\mathrm{R}_{\mathrm{t}}\right)+\alpha_{4} \Delta \ln \left(\pi_{\mathrm{t}}\right)+\alpha_{5} \Delta \ln \left(\mathrm{F}_{\mathrm{t}}\right)+\beta_{1} \ln \left(\mathrm{Y}_{\mathrm{t}-1}^{\mathrm{d}}\right)+$ $\beta_{2} \ln \left(\mathrm{T}_{\mathrm{t}-\mathrm{I}}\right)+\beta_{3} \ln \left(\mathrm{R}_{\mathrm{t}-1}\right)+\beta_{4} \ln \left(\pi_{\mathrm{t}-1}\right)+\beta_{5} \ln \left(\mathrm{F}_{\mathrm{t}-\mathrm{l}}\right)+\beta_{6} \ln \left(\mathrm{C}_{\mathrm{t}-1}\right)+\mu_{\mathrm{t}}$

The ECM embodies both the short-run dynamics and the long-run equilibrium of the series so that when the system is at rest, all the differences vanish and the long-run equilibrium relationship holds. The coefficient of the $\ln \left(\mathrm{C}_{t-1}\right)$ captures the speed of adjustment $\left(1-\beta_{6}\right)$ to changes in currency demand away from equilibrium currency holdings. It also allows for suitable economic interpretation of the results, while at the same it is robust to standard diagnostic testing.

Table 2. Dickey-Fuller Unit Root Tests

\begin{tabular}{|c|c|c|c|c|}
\hline \multirow[b]{2}{*}{$\begin{array}{l}\text { Optimal } \\
\mathrm{Lag}=1\end{array}$} & \multicolumn{2}{|c|}{ Levels } & \multicolumn{2}{|c|}{ First Differences } \\
\hline & $\begin{array}{c}\text { Constant } \\
\alpha_{1}=0\end{array}$ & $\begin{array}{c}\text { Constant and trend } \\
\alpha_{1}=\alpha_{2}=0\end{array}$ & $\begin{array}{c}\text { Constant } \\
\alpha_{1}=0\end{array}$ & $\begin{array}{c}\text { Constant and trend } \\
\alpha_{1}=\alpha_{2}=0\end{array}$ \\
\hline $\log \left(C_{t}\right)$ & -1.838 & -1.891 & -5.533 & -5.489 \\
\hline $\log \left(Y_{t}^{d}\right)$ & -0.415 & -1.610 & -4.082 & -4.188 \\
\hline $\log \left(T_{t}\right)$ & -1.892 & -2.513 & -7.464 & -8.248 \\
\hline $\log \left(R_{t}\right)$ & -1.577 & -1.412 & -5.266 & -5.267 \\
\hline $\log \left(\pi_{t}\right)$ & -0.374 & -1.837 & -3.701 & -3.751 \\
\hline $\log \left(F_{t}\right)$ & -2.664 & -2.591 & -6.931 & -7.376 \\
\hline
\end{tabular}

The following equation represents the augmented Dickey-Fuller Test with a constant:

$$
\Delta \mathrm{y}_{\mathrm{t}}=\alpha_{0}+\alpha_{1} \mathrm{y}_{\mathrm{t}-1}+\sum \mathrm{b}_{1} \Delta \mathrm{y}_{\mathrm{t}-1}+\varepsilon_{\mathrm{t}}
$$

and with time trend

$$
\Delta \mathrm{y}_{\mathrm{t}}=\alpha_{0}+\alpha_{1} \mathrm{y}_{\mathrm{t}-\mathrm{l}}+\alpha_{2} \mathrm{y}_{\mathrm{t}}+\sum \mathrm{b}_{1} \Delta \mathrm{y}_{\mathrm{t}-1}+\varepsilon_{\mathrm{t}}
$$

\footnotetext{
${ }^{13}$ Equation 2 could have been estimated in first differences since the unit root test established that all variables are I (1). However, doing so would not account for long-run behavior in the demand for currency.
} 
The null hypotheses are found at the top of the columns. The 5 percent critical (McKinnon) t-statistic for columns 2 and 4 is -2.945 and for columns 3 and 5 is -3.539 .

\section{Estimation results}

With the issue of stationarity resolved, the real currency equations were estimated using ordinary least squares (OLS) estimation techniques.

The results of the econometric estimation of the general model are reported in Table 3. All of the coefficients have the expected sign. Contemporaneous changes in taxes, interest rate, and income are however not significant. The diagnostic tests suggest that the model is wellspecified and could be reduced to derive a parsimonious and stable ECM. We searched for the most parsimonious model, by systematically dropping insignificant variables.

Table 4 summarizes the final version of our currency demand model estimated from 1964 to 2000 . The results indicate that the overall explanatory power of the model is strong, with adjusted R-squared of 0.83 . The coefficients indicate that in the long run, the demand for real currency is driven by inflation, taxes, and financial innovations while in the short run by changes in the inflation rate.

The coefficient on contemporaneous inflation is negative and significant, reflecting the opportunity costs of holding money, while the coefficient on financial innovations is negative, in line with expectations. The results indicate that the tax variable has no contemporaneous effect on real currency demand but has important effects with a one-period lag. The long-run elasticity of the average tax rate at -2.857 is extremely large indicating that he underground economy is strongly driven by the incentive for tax evasion. The model satisfies all of the basic diagnostic tests, as can be seen from Table 4 . The test for functional form (Ramsey RESET) shows no evidence of misspecification at the 5 percent significance level. Also, the Breusch-Godfrey and Arch tests indicate no evidence of serial correlation or heteroskedastic disturbances. Furthermore, the Jarque-Bera test statistic indicates that the errors are normally distributed. ${ }^{14}$

${ }^{14}$ Hendry (1995) provides a useful reference for these tests. 
Table 3. Estimation Results Unrestricted Model

Dependent Variable: First Difference of the Natural Logarithm Real Currency-Unrestricted Model

Data Series: $1964-2000$

\begin{tabular}{lccc} 
Variable & Coefficient & t-ratio & P-value \\
& & & \\
$+\ln \left(\mathrm{T}_{t}\right)$ & 0.061 & 0.511 & 0.614 \\
$+\ln \left(\mathrm{Y}^{\mathrm{d}}\right)$ & 0.199 & 0.658 & 0.517 \\
$+\ln \left(\mathrm{R}_{\mathrm{t}}\right)$ & -0.068 & 0.820 & 0.421 \\
$+\ln \left(\pi_{\mathrm{t}}\right)$ & -0.791 & 7.541 & 0.000 \\
$+\ln \left(\mathrm{F}_{t}\right)$ & 0.329 & 2.538 & 0.018 \\
$\ln \left(\mathrm{T}_{\mathrm{t}-1}\right)$ & 0.413 & 3.053 & 0.006 \\
$\ln \left(\mathrm{Y}_{\mathrm{t}-1}\right)$ & 0.036 & 0.215 & 0.832 \\
$\ln \left(\mathrm{R}_{\mathrm{t}-1}\right)$ & -0.004 & 0.057 & 0.955 \\
$\ln \left(\pi_{\mathrm{t}-1}\right)$ & -0.049 & 0.441 & 0.663 \\
$\ln \left(\mathrm{F}_{\mathrm{t}-1}\right)$ & 0.031 & 0.200 & 0.816 \\
$\ln \left(\mathrm{C}_{\mathrm{t}-1}\right)$ & -0.172 & 2.071 & 0.049 \\
Constant & -0.980 & 3.615 & 0.001 \\
& & & \\
Misspecification and diagnostic testing & & & \\
Number of observations & & 37 & \\
R-squared & & 0.811 & \\
L-M (Arch) test & & 0.599 & 0.445 \\
Breusch-Godfrey test & & 5.899 & $0.032{ }^{2 /}$ \\
Jarque-Bera normality & & 0.435 & 0.942 \\
Ramsey (RESET) test & & 0.882 & 0.425 \\
Average long-run tax rate ( $\eta)$ & -2.401 & \\
\hline
\end{tabular}

"The p-values indicate the probability of obtaining a test statistic whose absolute value is greater than or equal to that of the sample statistics if the null hypothesis is true. Thus, low p-values lead to the rejection of the null hypothesis.

2/ Null hypothesis is rejected at the 5 percent level. 
Table 4. Estimation Results Restricted Model

\begin{tabular}{|c|c|c|c|}
\hline \multicolumn{4}{|c|}{$\begin{array}{l}\text { Dependent Variable: First Difference of the Natural Logarithm } \\
\text { Real Currency-Restricted Model } \\
\text { Data Series: } 1964-2000\end{array}$} \\
\hline Variable & Coefficient & t-ratio & P-value \\
\hline$+\ln \left(\pi_{t}\right)$ & -0.743 & -10.11 & 0.000 \\
\hline $\ln \left(\mathrm{T}_{\mathrm{t}-1}\right)$ & 0.28 & -3.88 & 0.006 \\
\hline $\ln \left(\pi_{t-1}\right)$ & -0.555 & -7.717 & 0.000 \\
\hline $\ln \left(\operatorname{Innov}_{t-1}\right)$ & -0.056 & -1.948 & 0.061 \\
\hline $\ln \left(C_{t-1}\right)$ & -0.098 & -1.673 & 0.105 \\
\hline Constant & -0.436 & -3.126 & 0.004 \\
\hline \multicolumn{4}{|c|}{ Misspecification and Diagnostic Testing } \\
\hline Number of observations & & 37 & \\
\hline R-squared & & 0.830 & \\
\hline L-M (Arch) test & & 0.267 & 0.608 \\
\hline Breusch-Godfrey test & & 1.159 & 0.329 \\
\hline Jarque-Bera normality & & 2.552 & 0.279 \\
\hline Ramsey (RESET) test & & 0.782 & 0.405 \\
\hline Average long-run tax rate $(\eta)$ & & -2.857 & \\
\hline
\end{tabular}

\section{ESTIMATING THE UNDERGROUND ECONOMY}

Using equation (3) and the estimation results from Table 4, we can estimate the size of the underground economy in Guyana as follows. We begin by solving equation (3) for nominal currency holdings expressed in logarithms so that the estimated currency in the hands of the public at time (t) given observed average tax rates is given by the following:

$\Delta \ln \left(\mathrm{C}^{*} \mathrm{t}\right)=\left(-0.436+0.280^{*} \ln \left(\mathrm{T}_{\mathrm{t}-1}\right)-0.743 * \Delta \ln \left(\pi_{\mathrm{t}}\right)-0.555 * \ln \left(\pi_{\mathrm{t}-1}\right)-0.056^{*} \ln \left(\mathrm{F}_{\mathrm{t}-1}\right)-\right.$ $\left.0.098 \ln \left(\mathrm{C}^{*}{ }_{\mathrm{t}-1}\right)\right)+\Delta \ln \left(\mathrm{P}_{\mathrm{t}}\right)$,

where $\mathrm{C}_{\mathrm{t}}{ }^{*}=$ estimated nominal currency in the hands of the public in millions of Guyana dollars. A corresponding series of legal currency holdings was then derived by eliminating the tax variable in equation (4) and therefore the incentive for economic agents to participate in the underground economy. In the absence of this variable, the currency holdings by the 
public would be lower because there is less demand for cash payment of goods and services for the purposes of evading taxes. From values expressed in logarithms we converted them in level terms to yield estimates of nominal currency holdings with and without the tax variable. The difference between these two estimates yields estimates of nominal underground currency holdings in time $(\mathrm{t}) .{ }^{15}$

Assuming that the velocity of circulation of money is the same in both the official and underground economies, the GDP for the underground economy was obtained as the product of estimated underground currency holdings and the calculated velocity. ${ }^{16}$ Figures 1 and 2 show the size of the underground economy expressed as a percentage of official GDP and real GDP growth in the official and underground economies. Detailed yearly estimates are tabulated in Table 5.

${ }^{15}$ The sum of currency held by persons participating in the underground economy such that, underground currency $\left(\mathrm{IC}_{t}\right)$ is:

$\left(\mathrm{IC}_{\mathrm{t}=\mathrm{C}}{ }^{*} \mathrm{t}-\mathrm{C}^{*}{ }_{\mathrm{wt}}\right)$

${ }^{16}$ Given the assumption in the currency demand approach that cash is the predominant medium of payment to carry out economic and financial transactions in the underground economy, the velocity of circulation in the official economy was obtained by dividing official GDP by nominal money narrowly defined for the legal economy. Unfortunately, there is little that can be done about such an assumption. However, casual observations will suggest that the velocity of currency is likely to be higher in the underground economy, with the implication that our derived estimates may err on the side of underestimating the size of the underground economy. 
Table 5. Estimates of the Underground Economy and Tax Evasion, 1970-2000

\begin{tabular}{|c|c|c|c|c|c|c|}
\hline Year & $\begin{array}{c}\text { Underground } \\
\text { Currency } \\
\text { (Million G\$) } \\
\end{array}$ & $\begin{array}{c}\text { Legal } \\
\text { Currency } \\
\text { (Million G\$) } \\
\end{array}$ & $\begin{array}{c}\text { Underground } \\
\text { Economy } \\
\text { (Million G\$) }\end{array}$ & $\begin{array}{c}\text { Underground } \\
\text { Economy } \\
\text { (Percent of GDP) }\end{array}$ & $\begin{array}{c}\text { Maximum } \\
\text { Tax Collection } \\
\text { (Million G\$) } \\
\end{array}$ & $\begin{array}{c}\text { Maximum } \\
\text { Tax Collection } \\
\text { (Percent of GDP) }\end{array}$ \\
\hline 1970 & 18 & 37 & 104 & 27 & 21 & 5 \\
\hline 1971 & 18 & 41 & 120 & 29 & 27 & 6 \\
\hline 1972 & 20 & 57 & 183 & 41 & 46 & 10 \\
\hline 1973 & 23 & 64 & 190 & 40 & 46 & 9 \\
\hline 1974 & 30 & 88 & 289 & 55 & 98 & 12 \\
\hline 1975 & 33 & 117 & 388 & 49 & 159 & 16 \\
\hline 1976 & 42 & 91 & 215 & 21 & 68 & 7 \\
\hline 1977 & 46 & 186 & 552 & 60 & 163 & 18 \\
\hline 1978 & 66 & 175 & 430 & 47 & 119 & 12 \\
\hline 1979 & 75 & 147 & 286 & 28 & 82 & 8 \\
\hline 1980 & 71 & 186 & 461 & 44 & 133 & 11 \\
\hline 1981 & 76 & 191 & 443 & 37 & 158 & 14 \\
\hline 1982 & 82 & 260 & 641 & 55 & 240 & 22 \\
\hline 1983 & 102 & 288 & 644 & 59 & 277 & 27 \\
\hline 1984 & 121 & 418 & 1,000 & 97 & 416 & 34 \\
\hline 1985 & 157 & 487 & 1,096 & 91 & 470 & 34 \\
\hline 1986 & 192 & 586 & 1,276 & 91 & 656 & 43 \\
\hline 1987 & 516 & 1,154 & 1,452 & 96 & 527 & 21 \\
\hline 1988 & 555 & 1,562 & 2,199 & 89 & 969 & 30 \\
\hline 1989 & 2,322 & 3,642 & 3,206 & 101 & 1,013 & 12 \\
\hline 1990 & 568 & 3,391 & 6,763 & 82 & 2,339 & 19 \\
\hline 1991 & 4,359 & 9,253 & 10,786 & 88 & 3,531 & 12 \\
\hline 1992 & 413 & 3,175 & 12,728 & 43 & 6,299 & 18 \\
\hline 1993 & 2,444 & 6,959 & 15,178 & 43 & 6,356 & 15 \\
\hline 1994 & 3,127 & 9,436 & 21,175 & 51 & 7,542 & 14 \\
\hline 1995 & 3,915 & 9,185 & 17,771 & 33 & 6,765 & 11 \\
\hline 1996 & 4,131 & 9,668 & 18,614 & 29 & 7,368 & 10 \\
\hline 1997 & 4,475 & 11,122 & 22,255 & 32 & 7,775 & 10 \\
\hline 1998 & 1,851 & 10,618 & 29,327 & 38 & 10,013 & 13 \\
\hline 1999 & 5,204 & 15,908 & 35,662 & 45 & 11,275 & 12 \\
\hline 2000 & 6,096 & 14,850 & 32,385 & 35 & 11,380 & 12 \\
\hline
\end{tabular}

Note: Ratios are in percent of official GDP. 
Figure 1. Guyana: The Underground Economy, 1970-2000 (3-year moving average)

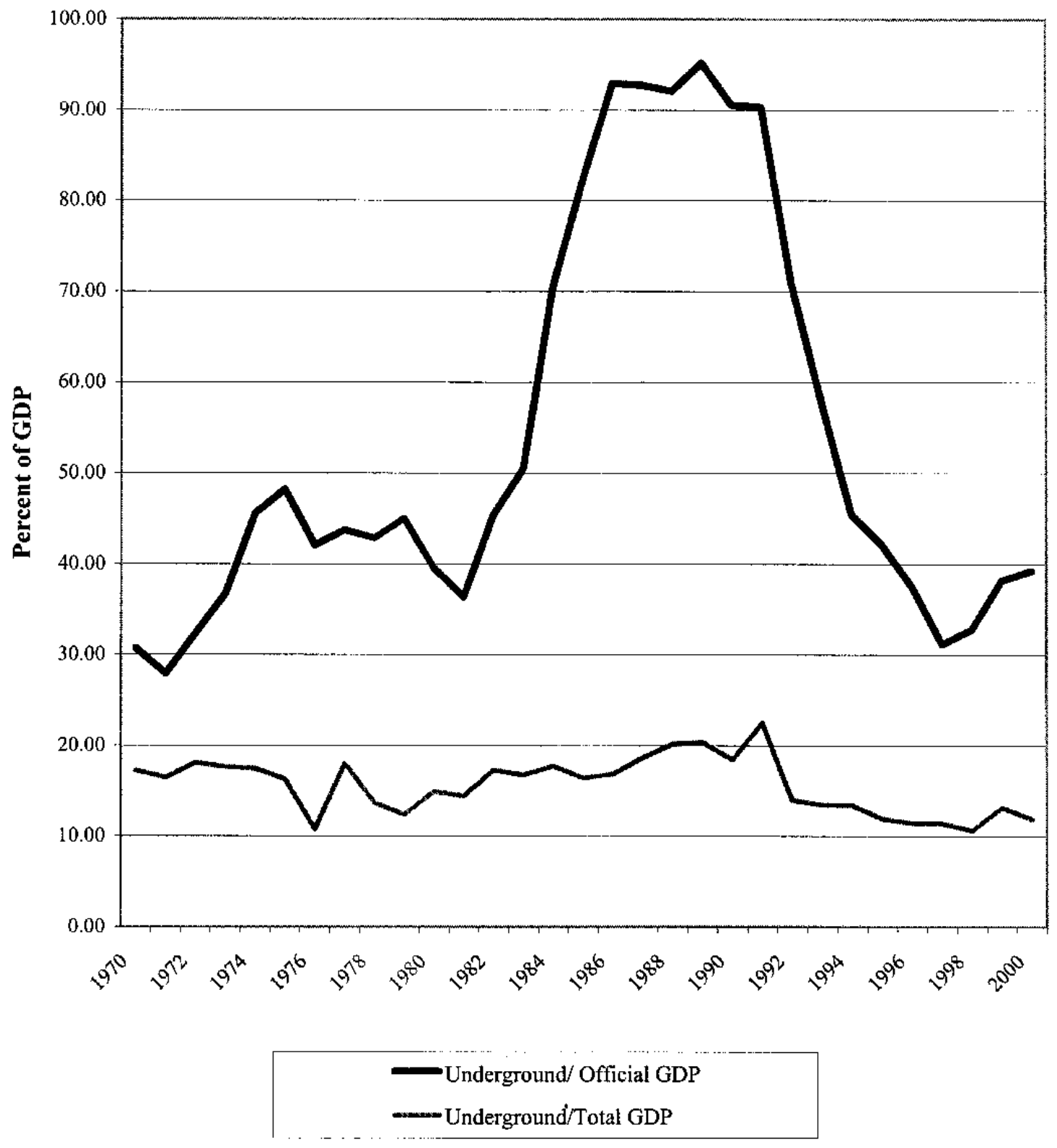

Sources: Bank of Guyana and Bureau of Statistics. 
Figure 2. Guyana: Real Growth Rates, 1970-2000

(3-year moving average)

(a) Official and Underground Economy

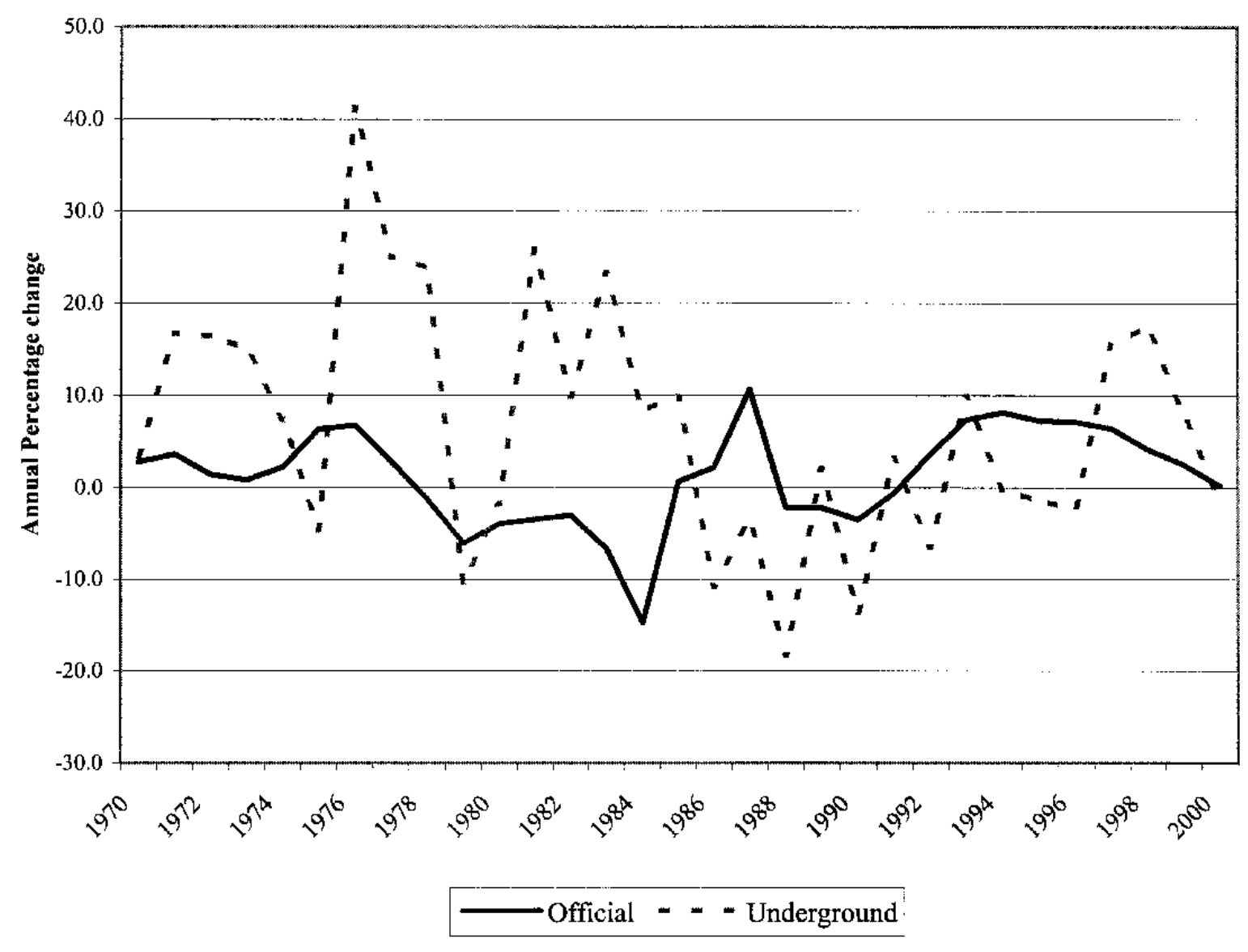

(b) Simulated Total Economic Growth

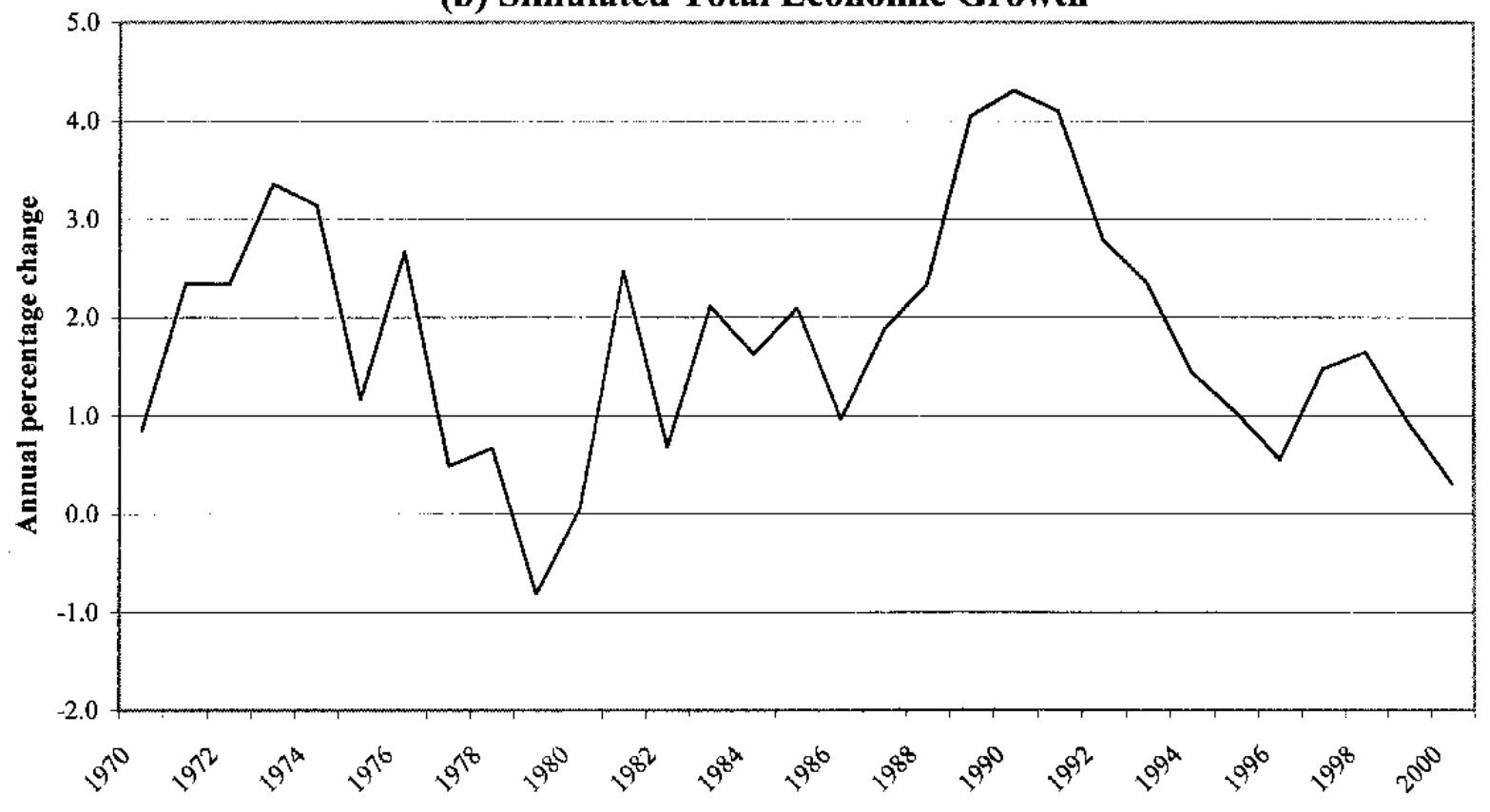

Sources: Bank of Guyana and Bureau of Statistics. 


\section{Interpretations}

Figure 1 and estimates in Table 4 confirm the presence of a large underground economy in Guyana, representing a significant part of overall economic activity. Figure 1 shows significant fluctuations, with an upward trend in the size of the underground economy as a percentage of official GDP, which averaged about 40 percent of GDP in the $1970 \mathrm{~s}$, before increasing sharply to an average of 76 percent of official GDP during 1980-89. The increase in the 1980 s reflected mainly excessive government regulation and inward-looking economic policies that were the norm at that time. By 1989, the underground economy reached 66 percent of official GDP and two years later in 1991 reached 73 percent of official GDP. During the 1990s the size of the underground economy fell, but at an average of 47 percent, is still higher than the levels of two decades earlier.

The share of the underground economy in total GDP (Figure 1) has been relatively stable over the period 1970-89 despite the fluctuations in the official economy. This is not surprising given the very low average growth of real GDP in the official economy during this period. Also, it may be due, in part, to the fact that increases in real incomes have tended to push people into higher marginal tax brackets and that regulations and controls were not relaxed even in periods when the economy was expanding. In addition, since production and distribution of almost all goods and services were confined to public enterprises, increases in income were being funneled into investments in the underground sector that are difficult to tax and control.

Figure 2a shows the path of real GDP growth in the underground and official economies. There appears to be no systematic relationship between real changes in the official and underground economies. Surprisingly, the computed coefficient of correlation between the real official and underground growth rates is negative and very low $(-0.05)$. This implies that cyclical movements in the underground economy tend not to coincide with movements in the official economy.

Also, Figures $2 \mathrm{a}$ and $2 \mathrm{~b}$ show that the average annual growth of the official economy during the sample period at 1.3 percent was significantly lower than the 6.7 percent growth in the underground economy. The latter grew much faster than the official economy in the 1980s, but declined sharply in the 1990 s, mostly due to the consolidation of productive activities back into the official sector. The variance of growth in the underground economy was significantly higher than that in the formal economy during the $1980 \mathrm{~s}$, indicating more volatility in overall economic growth than the official statistics would indicate during that period. $^{17}$

${ }^{17}$ The standard deviation of real growth in the underground during 1970-2000 was about 13 compared with 5 in the official economy. 


\section{TAX EVASION}

A natural extension of the analysis in the preceding sections is to ask what is the impact of the existence of a large underground economy and its variability for tax policy in Guyana. In other words, to what extent can the observed tax rates and estimates of the underground cconomy provide insights to the level and proliferation of tax evasion as shown in Table 5. To examine this issue, a series is constructed for the entire sample period for the upper bound approximation of the potential revenue that the government could collect if the underground economy could be taxed. The series is derived using the product of the cstimate of the size of the combined official and the underground economy at time $t$ and the average tax rate. This indicates that on average, if the underground economy had been incorporated in the official sector, government revenue would have becn higher by, at least, an estimated 7 percent of formal GDP per year over period 1970-2000 (Figure 3). ${ }^{18}$

Thus, the widespread tax evasion associated with the underground economy has de facto increased the fiscal deficit and contributed to unsustainable debt dynamics.

\section{Conclusion}

The objective of this study was to estimate and analyze the size and consequences of the underground economy in Guyana using a parsimonious and stable error-correction-based currency demand model. Our findings indicate the existence of a large underground economy in Guyana. While the share of the underground economy fell substantially following the implementation of economic reform programs beginning in 1989, it still remained high in the 1990s. The underground economy may have included activities such as cross-border smuggling of exports like gold and diamonds and of imports of fuel and other consumer goods; as well as private professional and informal services and various other illegal activities.

The existence of a sizable underground economy of unrecorded domestic and international economic transactions suggests that the existing national accounts series are not adequate for meaningful economic analysis or for policy formulation. Efforts must be made by the national authorities to establish credible estimates of the key components of the underground economy with a view to incorporating them in the compilation of official statistics.

\footnotetext{
${ }^{18}$ For illustrative purposes, the paper assumes a tax yield of 50 percent from maximum collectible taxes.
} 
Figure 3. Guyana Tax Revenue, 1970-2000

(a) Actual and Potential Tax Revenues to Official GDP 1/

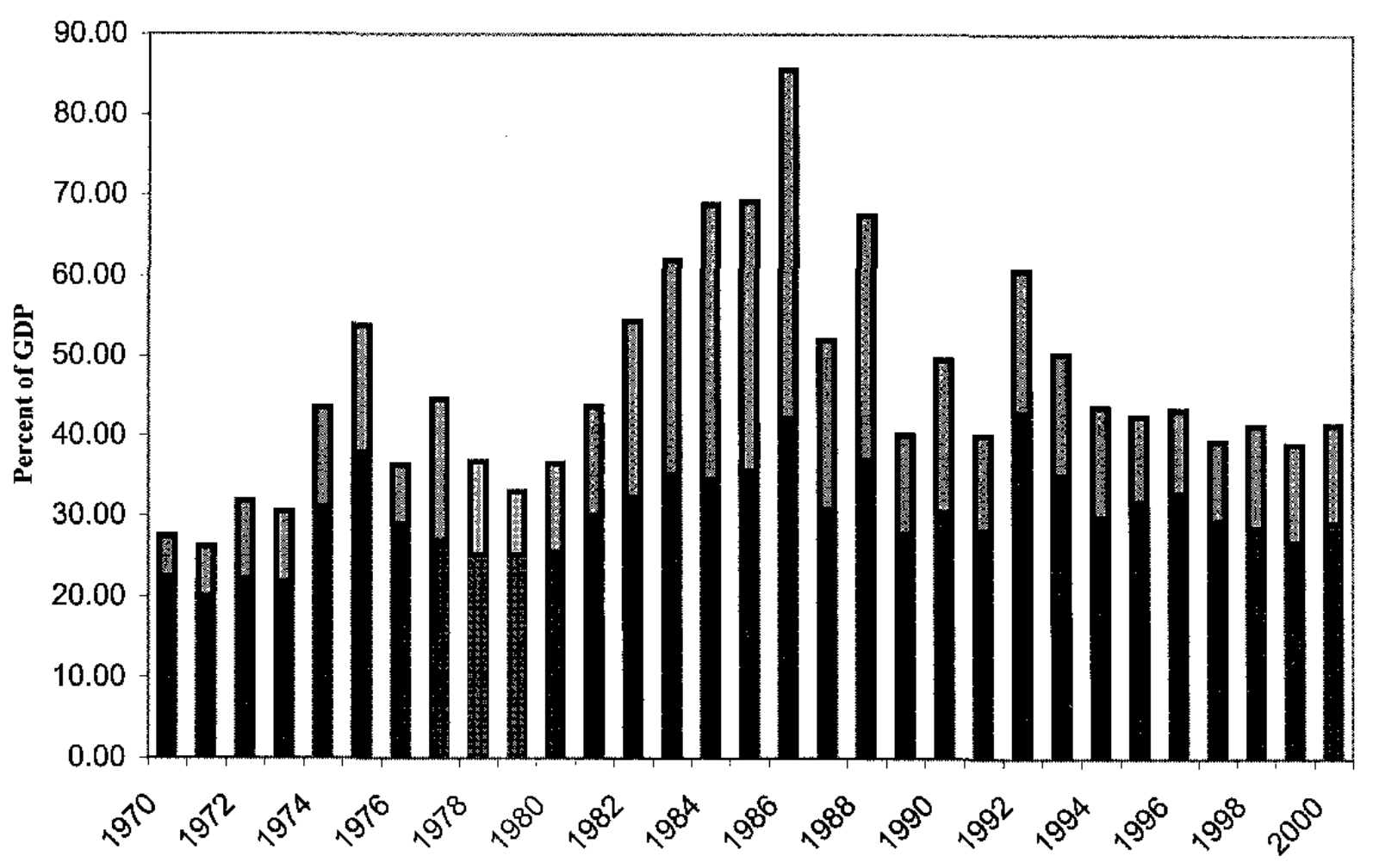

DTax Evasion/Official GDP

Actual/Official GDP

(b) Actual and Potential Tax Revenues to Total GDP

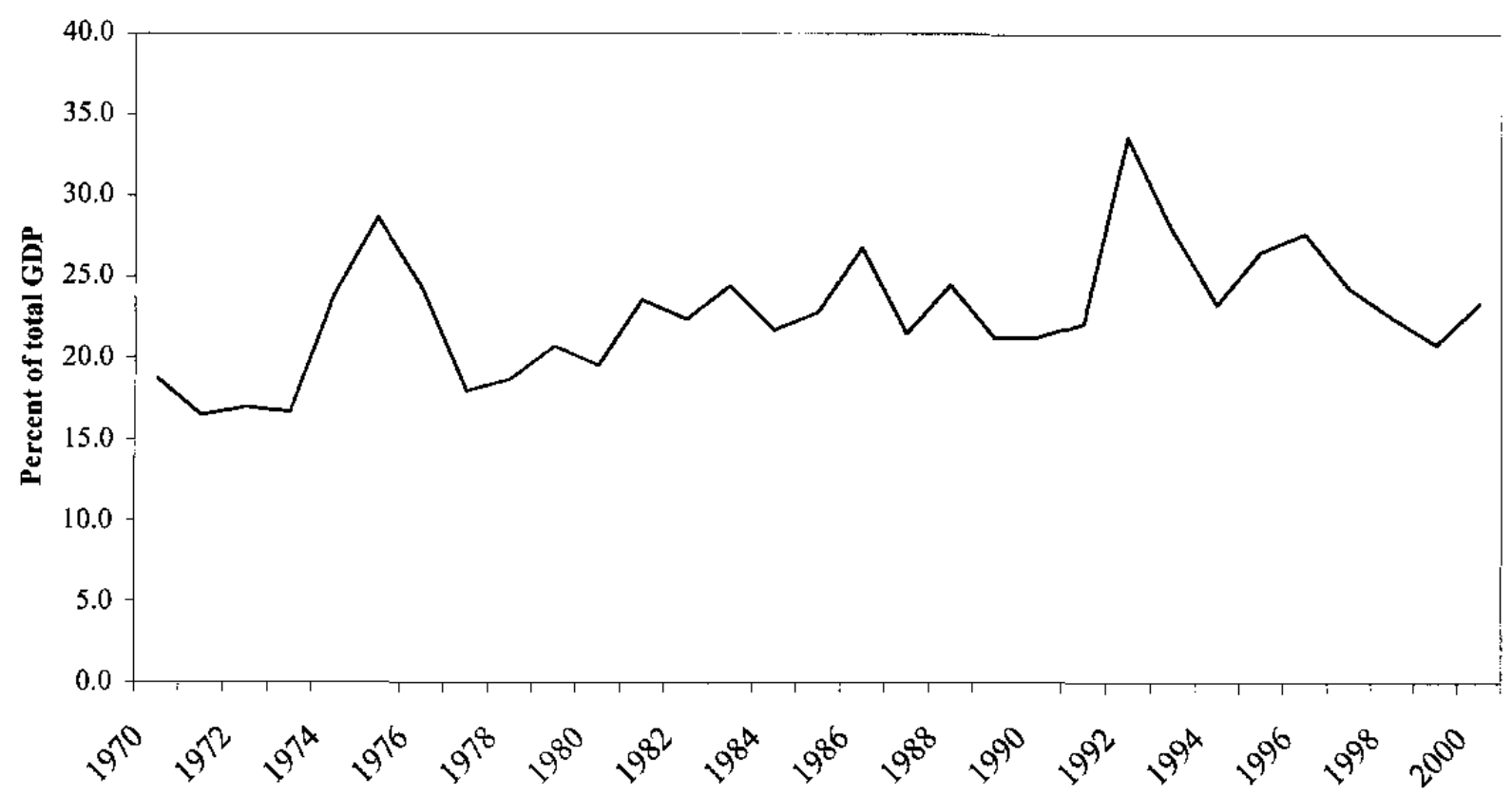

1/ Assumes a tax yield of 50 percent from maximum collectible taxes. 
Although the total elimination of the underground economy is impossible, it is imperative that the government considers implementing policies to reduce its size. The relative decline in the size and growth rate of the underground economy during the 1990s, when compared with the preceding two decades, has shown that a long-run strategy based on market-based reforms, including fiscal reforms, along with improved governance and stronger institutions, are effective in meeting these goals. A comprehensive reform of the current tax system and its administration as well as deregulation and an improved provision of government services (such as land titling, domestic security, and judicial services), would likely help reduce the size of the underground economy. 
Guyana: Summary of the Tax System

As of December 31, 2001

Tax (Taxpayer) Description/Tax Base

Rates

Deductions and Main Exemptions //

\section{Income Tax}

(a) Personal and corporate: Individuals and corporations reccivin income earncd from carrying out productive aclivilies (including the rendering of services) within the territory of the Republic of Guyana.

\section{(b) Withholding}

Individuals and corporations

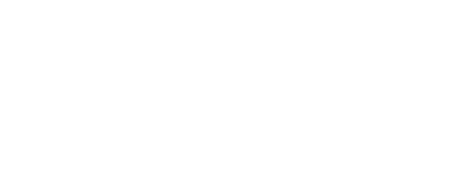

Payments other than interest to nonresidents.

\section{Intercst earned on:}

(i) Interest bearing deposit accounts
Tax base:

The total amount of net taxable inconc-whether in money or in kind - earned by the taxpayer (gross income lcss expenses and deductions).

\section{Personal:}

Individuals pay rates of 20 percent on annual income exceeding $0 \$ 216,000$ but below G\$350,000 (monthly income exceedin $\mathrm{G} \$ 18,000$ but below $\mathrm{G} \$ 29,083$ ); and $33 \frac{1}{3}$ percent on annual income from $\mathrm{G} \$ 350,000$ upwards (monthly income from G $\$ 29,083$ upwards).

\section{Corporate:}

1. Commercial corporations-45 percent

2. Corporations other than commercial35 percent

Companies pay a minimum tax of 2 percent.

This is credited when they return to

profitability.

(ii) Loans secured by bonds and similar instruments.

15 percent

15 percent

10 percent
Deductions:

Threshold: G\$216,000 per year.

\section{Excmpted types of income:}

I. Donations to charitable organizations

2. Dividends.

3. Annual leave passage allowances to traditional public scrvants (which equals one month salary)

4. Interest and other income which attracts withholding tax.

\section{Exempted persons or entities:}

1. Disabled individuals and senior citizens whose total annual incone does not cxceed G $\$ 216,000$

2. Charitable organizations 
Gross sales to the Gold Board by individual gold miners.

2 percent

Income generated from entertainment, foreign artist. and cinemas.

25 percent

3. Premium

4. Property Taxes

(a) Propert

b) Process Fee (previously cstate duty)

Heirs or Recipients
Tax paid on insurance premiums to:

(i) Nonresident companies carrying on business in

Guyana.

Guyana

6 percent

10 percent

Tax hase: Personal

(i) On the first $G \$ 7,500,000$ of net property

Zero rate

(ii) For every dollar of the next G\$5,000,000 of net property

$1 / 2$ percent

(iii) For every dollar of the remainder of the net

property

$3 / 4$ of 1 percent

Tax base: Corporate.

(i) On the first $G \$ 1,500,000$ of net property.

(ii) For every dollar of the next $G \$ 5,000,000$ of net

property.

(iii) For every dollar of the remainder of the net property.

Estates with gross value exceeding $(\$ \$ 100,000$ (ii) Nonresident companies not carrying on business in
Zero rate

$1 / 2$ percent

$3 / 4$ percent

$1 / 2$ of 1 percent

\section{Exempted types of income:}

1. Treasury bill discounts earned by commercial banks.

\section{Exempted types of income:}

Performances by Caribbean and nonresident Guyanese artists.

\section{Exempted persons/entities:}

1. United Nations officials and members of consular services

2. Any expert, adviser, technician or official

whose salary is not payable by the Government of

Guyan:

3. Local authorities

4. Charitable organizations 
Tax paid on the accumulated retail value of vehicles purchased, based on engine capacity:

(i) Under $1500 \mathrm{cc}$

10 percent

(ii) From $1500 \mathrm{cc}$ to $2000 \mathrm{cc}$

(iii) From $2000 \mathrm{cc}$ to $3000 \mathrm{cc}$

(iv) From $3000 \mathrm{cc}$ and above
20 percent

70 percent

100 percent

\section{Travel Taxes}

a) Travel voucher tax

b) Travel tax

7. Import Dutird

Any individual or corporation importing goods liable to taxation.
Tax paid on the cost of any airline ticket for which the 10 percent journey originatcs in Guyana

Tax exit requited to be paid by passengers departing

Guyana

G $\$ 2,500$ per passenger

All goods liable for taxation that are imported into Guyana.

Tax base: The c.if., value of the merchandise

0-20 percent

Gencral rates

40 percent

Special rates (natural agricultural products)

Motor vehicies

Luxury items

45 percent

100 percent

5 percent

Aquarium fish - value of export

Shrimp

Bauxite - tonne
1 percent

G\$0.45
Disposal of public corporation shares

\section{Exempted persons/ entities}

1. Eligible remigrants and public servants for vehicles $2000 \mathrm{ec}$ and below

2. Members of parliament and members of the diplomatic corps

\section{Exempted persons or entities:}

1. Children under seven years of agc

2. United Nations officials and members of permanent consular services

\section{Exempted companies/Items}

1. All oil conmodities imported by mining companies.

2. Imports originated from CARICOM countries.

3. Fucl imported from Venezuela and Curacao.

4. Eligible remigrants and public servants

(vehicles).

5. Certain manufacturing equipment and raw materials.

\section{Exempted Items}

1. Manufactured articles

2. Goods other than bauxite and sugar exported to another community statc. 
Timber

Rough green hard logs - cubic meter

Sawn green hard wood - cubic meter

Live birds - value of export

Sugar - tonne

All other articles

\section{Tax Base:}

On imported goods.

The c.i.f. value of the merchandise plus:

(i) Value of duty paid on oil imports

(ii) Value of duty paid on nonoil imports.

On local goods:

(i) Sales value of alcoholic beverages.

(ii) Production cost of tobacco.

(iii) Other goods:

Primary inputs and capital goods

Intermediate inputs and finai goods

On local services:

(i) Value of overseas telephonc calls

(ii) Betting shops - value of the bet
G\$0.29

G\$5.09

3. Forest products other than those mentioned under tax base.

4. Agriproducts and by product other than sugar and molasses.

1.5 percent

G\$1 (deposited in Sugar Industry Stabilization Fund).

$1 \frac{1}{2}$ percent

\section{0 percent}

$0-30$ percent

L. Partial exemption granted for the importation of motor vehicles by public servants and eligible remigrants.

2. Certain manufacturing equipment and raw materials. 


\section{References}

Bagachwa, M.S.D., and A. Naho, 1995, "Estimating the Second Lconomy in Tanzania," World Development, Vol. 23, No. 8, pp. 1387-99.

Bajada, C., 1999, "Estimates of the Underground Economy in Australia," Economic Journal, Vol. 75, pp. 369-84.

Banerjee, A., D. Dolado, J. W. Galbraith, and D. F. Hendry, 1993, "Cointegration, Error Correction, and the Econometric Analysis of Nonstationary Data," (Oxford Press) Oxford University.

Baumol, W., 1952, "The Transaction Demand for Cash: An Inventory Theoreotical Approach," Quarterly Journal of Economics, Vol. 66, pp. 545-56.

Bennett, K. M., 1995, "Economic Decline and The Growth of the Underground Sector: The Guyana and Jamaica Experience," Journal of International Development, Vol. 7:2, pp. 229-42.

Bhattacharyya, D.K., 1990, "An Econometric Method for Estimating the Underground Economy," Economic Journal, Vol. 100, pp 661-69.

, (1999), "On the Economic Rationale of Estimating the Hidden Economy," Economic Journal, Vol. 109, pp. 348-59.

Cagan, P., 1958, "The Demand for Currency Relative to Total Money Supply," Occasional Paper No. 52, New York: National Bureau of Economic Research.

Carson, C.S., 1984, "The Underground Economy: An Introduction (Measurement Methods)," Survey of Current Business, Vol. 64, May, pp. 21-37.

Commission of European Communities, International Monetary Fund, Organization for Economic Corporation and Development, United Nations, World Bank, 1993, "System of National Accounts 1993," (New York: United Nations).

De Leeuw, F., 1985, "An Indirect Technique for Measuring the Underground Economy," Survey of Current Business, Vol. 64 (May), pp. 21-37.

Dixon, H., 1999, "Controversy: On the use of the Hidden Economy Estimates," Economic Journal, Vol. 109, pp 335-37. 
Egoume-Bossogo, P., E. Faal, R. Nallari, and E. Weisman, 2002, "Guyana-Experience With Macroeconomic Stabilization, Structural Adjustment, and Poverty Reduction," IMF Occasional Paper, forthcoming.

Feige, E.L., 1979, "How Big Is The Irregular Economy," Challenge, Vol. 22, pp. 5-13.

- 1989 , "The Underground Economies: Tax Evasion and Information Distortion," (Cambridge, England: Cambridge University Press).

__ 1990), "Defining and Estimating the Underground and Underground Economies: The New Institutional Economies Approach," World Development, Vol. 18, No. 7 , pp. $989-1002$.

Frey, B.S. and W.W. Pommerehne, 1984, "The Underground Economy: State and Prospects for Measurement," Review of Income and Wealth, Vol. 30, pp. 1-23.

Frey, B.S., and H. Weck, 1983, "Estimating the Underground Economy: A Naïve Approach," Oxford Economic Papers, Vol. 35, pp. 23-44.

Gaertner, W., and A. Wenig, 1985, "The Economics of the Underground Economy," Proceedings of the International Conference on the Economics of the Underground Economy, Germany, (Berlin; New York: Springer-Verlag).

Garcia, G., 1978, "The Currency Ratio and the Subterranean Economy," Financial Analyst Journal, Vol. 32, pp. 1-5.

—, and S., Pak 1979, "The Ratio of Currency to Demand Deposits in the United States," Journal of Finance, Vol. 34, pp. 703-15.

Guttman, P. M., 1977, “The Subterranean Economy," Financial Analyst Journal, November-December, pp. 26-34.

Hamilton, J.D., 1994, "Time Series Analysis," (Princeton: Princeton University Press).

Hendry, D., 1995, “Dynamic Econometrics," (Oxford: Oxford University Press).

Johansen, S. (1988), "Statistical Analysis of Cointegration Vectors," Journal of Economic Dynamics and Control, Vol. 12, pp. 231-54. , and Juselius, K., 1990, "Maximum Likelihood Estimation and Inference on Cointegration-With Applications to the Demand for Money," Oxford Bulletin of Economic and Statistics, Vol. 52, pp. 169-211. 
Klovland, J.T., 1984, "Tax Evasion and the Demand for Currency in Norway and Sweden: Is There an Underground Relationship?" Scandinavian Journal of Economics, Vol. 86, No. 4, pp. 423-39.

Lewis, D.E., 1987, "The Economics of Crime: A Survey," Economic Analysis and Policy, Vol. 17, No. 2, pp. 195-219.

McKinnon, J.G., 1991, "Critical Values for Cointegration, in Long Run Economic Relations," in C.W. Granger and R.F. Engel, (Oxford: Oxford University Press).

Nickell, S., 1985, "Error Correction, Partial Adjustment and All That: An Expository Note," Oxford Bulletin of Economics and Statistics, Vol. 47, pp. 119-29.

O'Higgins, M., 1985, "The Relationship Between the Formal and Underground Economies: An Exploratory Analysis for Four Countries," W. Gaertner and A. Wenig.

Pyle, D.J., 1989, "Tax Evasion and the Black Economy," (London: Macmillan).

Schneider, F., and Enste, D.H., 2000a; "Estimating the Size of the Danish Shadow Economy Using the Currency Demand Approach," Scandinavian Journal of Economics, Vol. 88 , No. 4 , pp. $643-68$.

- 2000b, "Shadow Economies: Size, Causes, and Consequences," Journal of Economic Literature, Vol. 38, pp. 77-114.

Shabsigh, Ghiath, 1995 "The Underground Economy: Estimations and Economic Policy Implications: The Case of Pakistan," IMF Working Paper 95/101 (Washington: International Monetary Fund).

Tanzi, V., 1980, "The Underground Economy in the United States: Estimates and Implications," Banca Nacionale del Lavaro Quarterly Review, Vol. 35, pp. 427-53.

__ 1980b, "The Underground Economy in the United States: Annual Estimates, 1930-80," IMF Staff Papers , Vol. 30 (June), pp. 283-305.

- 1982, "The Underground Economy in the United States and Abroad," (Lexington, Massachusetts: Lexington Books).

_ 1999 , "Uses and Abuses of the Estimates of the The Underground Economy," Economic Journal, Vol. 109, pp. 338-340.

Thomas, C.Y., 1989, "Foreign Currency Black Markets: Lessons from Guyanese Experience," Social and Economic Studies, Vol. 38, No. 2, pp. 137-84. 
Tucker, M., 1982, "The Underground Economy in Australia," in V. Tanzi (1982).

Zilberfarb, B.Z., 1986, "Estimates of the Underground Economy in the United States: A Comment on Tanzi," IMF Staff Papers, Vol. 33, No. 4, pp. 790-98. 